\section{ANDROMORPHIC FEMALE OF THE DRAGONFLY NEUROTHEMIS TULLIA TULLIA (DRURY) (ODONATA: LIBELLULIDAE), CENTRAL INDIA}

\section{Raymond J. Andrew}

Post Graduate Department of Zoology, Hislop College, Nagpur, Maharashtra 440001, India

rajuandrew@yahoo.com

Most anisopteran libellulid odonates are sexually dimorphic when mature. The males acquire bright colouration since colours and patterns on the wings and body may play an important role in territoriality and courtship (Andrew et al. 2008). Neurothemis tullia tullia is a common Indian dragonfly which occurs in large colonies in swamps and heavily-weeded tanks. It lies close to the herbage, perched on twigs, aquatic weeds along the border not more than five feet above the ground and has a weak, slow fluttering flight. It is a libellulid which shows an extreme case of sexual dimorphism in colour and patterns on the wings.

In Neurothemis tullia tullia, the male has a black face and the eyes are blackish-brown above and olive green below. The thorax is black with a mid-dorsal cream stripe. The basal half of the wings is opaque blue black which is bordered by a milky white patch towards the tip. The wing tips are transparent. The abdomen is black with a mid dorsal creamy white stripe on the upper side. The female differs significantly from the male in body marking, colouration and wing spots. The face is olive green while the eyes are pale brown above and pale olive green towards the sides and below. The thorax is greenish-yellow with a bright yellow mid dorsal stripe which is bordered with a black stripe. The wing base is amber yellow while the front edge is blackish-brown which forms a very large brown black spot. In the hind wing, this spot is irregular and sickle shaped. The wing tips are broadly blackish-brown. The abdomen is bright yellow with a broad black band above. The underside is black (Subramanian 2005). Observation

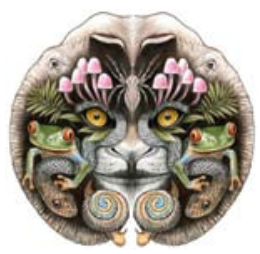

ISSN Print 0974-7893

\section{OPEN ACCESS}

Online 0974-7907 of andropmorphs is very rare in Anisoptera and generally restricted to certain genera such as Crocothemis, Neurothemis and Sympetrum (Kumar 1988; Kotarac 1996; Corbet 1999; Prasad et al. 2000).

The collection site of this odonate was the western border of Telenkhedi Pond $\left(20^{\circ} 9^{\prime} \mathrm{N} \& 79^{\circ} 9^{\prime} \mathrm{E}\right)$ located at the foothills of the Seminary Hillock of Nagpur City of central India (Image 1). This section of the pond is rich with submerged (Hydrilla sp.), floating (Nymphea sp., Eichornnia sp.) and marginal (Ipomea sp., Eleocharis sp., Fimbristylis sp., Cleome sp., Alternanthera sp. and Eriocaulon sp.) aquatic flora. Along with Neurothemis tullia tullia, the other anisopteran libellulids found

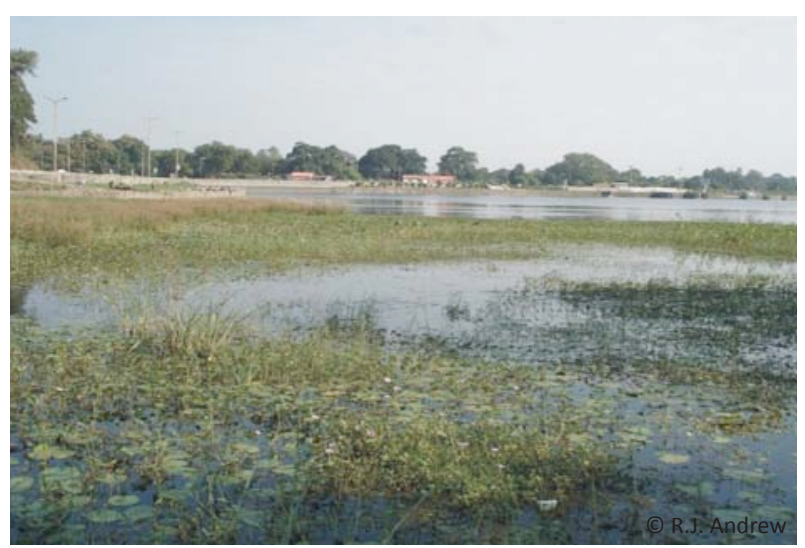

Image 1. Site of collection - west border of Telenkhedi Pond of Nagpur City

DOI: http://dx.doi.org/10.11609/JoTT.o3143.155 | ZooBank: urn:Isid:zoobank.org:pub:A9F7F3F4-C42D-4071-B79D-9F823F552496

Manuscript details: Ms \# 03143 | Received 30 March 2012 | Final received 01 November 2012 | Finally accepted 14 November 2012

Citation: Andrew, R.J. (2013). Andromorphic female of the dragonfly Neurothemis tullia tullia (Drury) (Odonata: Libellulidae), central India. Journal of Threatened Taxa 5(1): 3571-3573; doi:10.11609/JoTT.03143.155

Copyright: (c) Andrew 2013. Creative Commons Attribution 3.0 Unported License. JoTT allows unrestricted use of this article in any medium, reproduction and distribution by providing adequate credit to the authors and the source of publication.

Funding: The work was self funded.

Competing Interest: None.

Acknowledgements: I thank my students, Nilesh Thaokar and Payal Verma for their help in collection of the sample. I am grateful to Dr. Ms. Dipti R. Christian, Principal, Hislop College, Nagpur for the laboratory facilities. 
breeding around this vicinity were Crocothemis servilia, Orthetrum sabina sabina, Rhyothemis variegata variegata, Brachythemis contaminata and Acisoma panorpoides panorpoides. The odonates were identified with the help of identification keys provided by Fraser (1936) and aquatic plants were determined using Ugemuge (1986).

\section{Observation}

On 02 November 2010, we were observing the dragonflies of Telenkhedi Pond (west end) when we noticed a typical "male" of Neurothemis $t$. tullia behaving in an unusual manner. It was hovering above the shallow shore and flying low at regular intervals so as to dip the terminal abdominal segment in water, which is a typical female ovipositing behaviour of this species.

We managed to collect this specimen and were surprised to observe that although it appeared like a male,

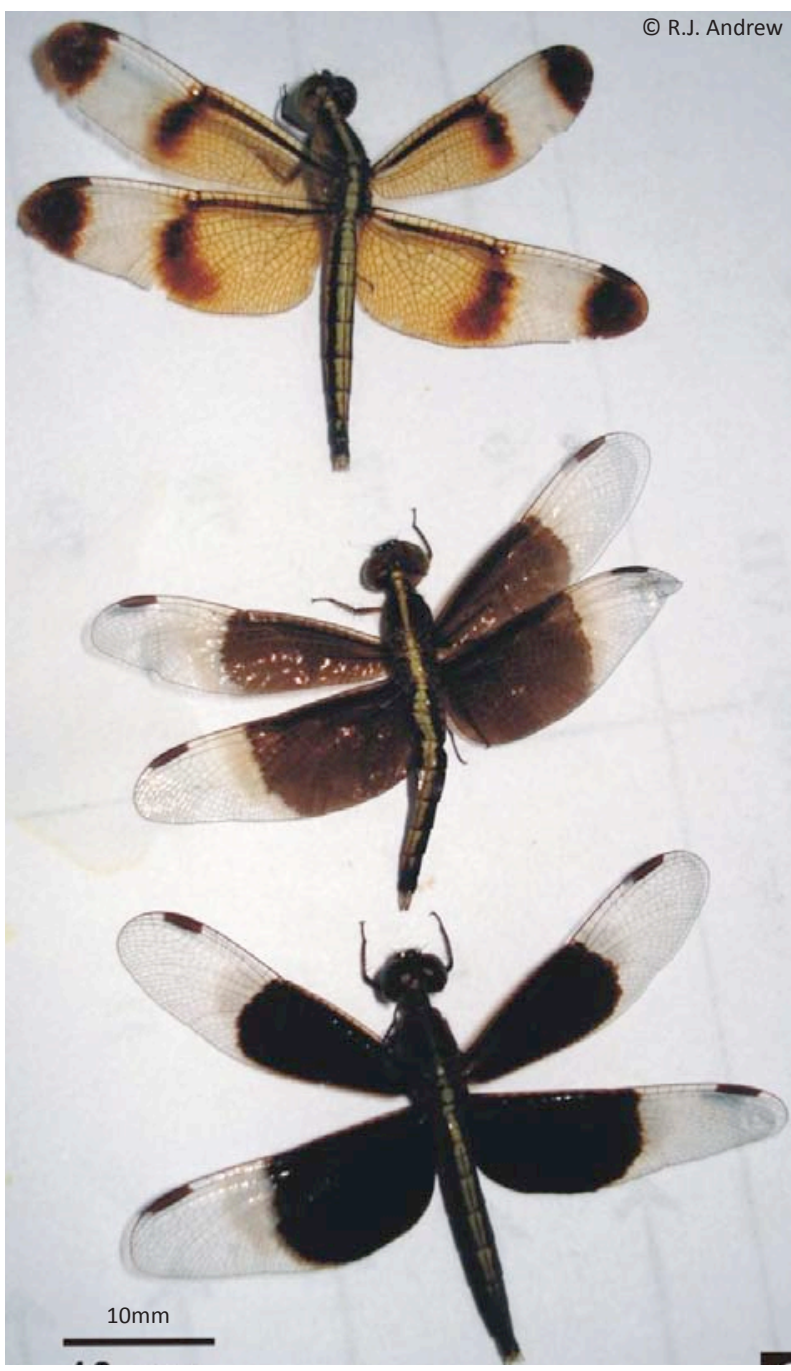

Image 2. Neurothemis t. tullia - female (top), andromorphic female (middle) and male (bottom).

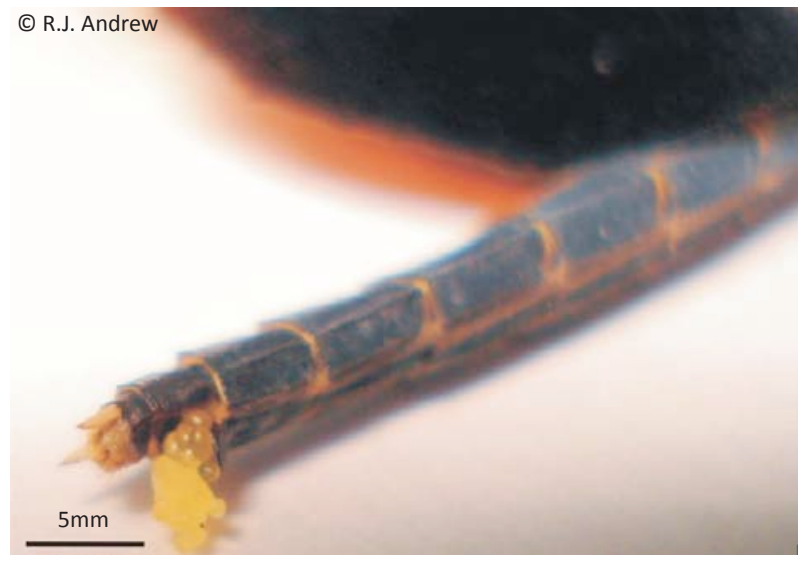

Image 3. Andromorphic Neurothemis t. tullia releasing egg clutch.

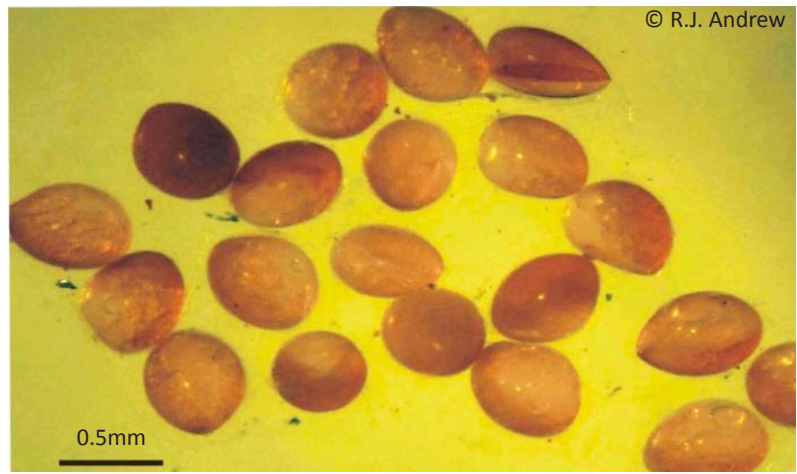

Image 4. Viable eggs of andromorphic Neurothemis $t$. tullia.

the male secondary copulatory apparatus on the venter of the second and third abdomen was missing (Image 2). Further observation revealed that it had only two anal appendages, a typical character of female odonates. Later in the laboratory we dipped her abdomen in water, mimicking oviposition behaviour and this 'male-like' specimen released a clutch of spherical eggs (Image 3). The shape and size of the eggs was comparable with the eggs deposited by normal females. We collected the eggs (Image 4) and they developed within an average period of 11-15 days to produce first larva (or nymph). This specimen was a sexually mature, gravid andromorphic female of Neurothemis $t$. tullia. Table 1 describes and compares the various colour and wing spot patterns of the andromorphic female with the normal male and female of Neurothemis t. tullia (Image 2).

\section{Discussion}

Andromorphs are very rare in libellulid Anisoptera and their frequency is variable among populations and varies positively with male density. Andromorph females are commonly found in Zygoptera where it represents true polychromatism (Corbet 1999). In Zygoptera, 
Table 1. Comparison of the colour and wingspot pattern of andromorphic female with normal male and female of Neurothemis $t$. tullia

\begin{tabular}{|c|c|c|c|c|}
\hline $\begin{array}{l}\text { Neurothemis } \\
\text { tullia tullia }\end{array}$ & Male & Andromorphic female & Female & Remark \\
\hline Head- Face & Black & Black & Olive green yellow & Similar to male. \\
\hline Eyes & $\begin{array}{l}\text { Black brown above with } \\
\text { olive green below }\end{array}$ & $\begin{array}{l}\text { Dark brown above olive green } \\
\text { below }\end{array}$ & Pale brown above, pale olive green below & Similar to male. \\
\hline Thorax & $\begin{array}{l}\text { Black with a mid-dorsal } \\
\text { cream stripe. }\end{array}$ & $\begin{array}{l}\text { Blackish-brown with a mid-dorsal } \\
\text { cream stripe. An olive green band } \\
\text { along the lateral upper level is } \\
\text { present }\end{array}$ & $\begin{array}{l}\text { Greenish-yellow with a bright yellow mid } \\
\text { dorsal stripe bordered black. }\end{array}$ & $\begin{array}{l}\text { Similar to male, except } \\
\text { for the lateral olive green } \\
\text { band. }\end{array}$ \\
\hline Legs & Black & Black & Outer surface yellow, inner black & Similar to male. \\
\hline Wings & $\begin{array}{l}\text { Basal half opaque blue/ } \\
\text { brown black with a } \\
\text { white broad border } \\
\text { towards the tip. Wing } \\
\text { tips transparent. }\end{array}$ & $\begin{array}{l}\text { Basal half opaque brownish black } \\
\text { with a white broad border towards } \\
\text { the tip. Wing tips transparent. }\end{array}$ & $\begin{array}{l}\text { Base of wings amber yellow. Front edge of } \\
\text { the wing blackish brown which forms a broad } \\
\text { large dark brownish spot. In the hind wing } \\
\text { this spot is irregular sickle-shaped. Wing tips } \\
\text { are broadly blackish brown. }\end{array}$ & $\begin{array}{l}\text { Similar to male in } \\
\text { patterning but the basal } \\
\text { half spot is one shade } \\
\text { lighter. }\end{array}$ \\
\hline Abdomen & $\begin{array}{l}\text { Black with a broad mid- } \\
\text { dorsal creamy white } \\
\text { stripe on the upper } \\
\text { side. }\end{array}$ & $\begin{array}{l}\text { Dark brown with a broad mid- } \\
\text { dorsal creamy white strip on the } \\
\text { upper side, but a thin strip of olive } \\
\text { green along the lateral margins of } \\
\text { the first four abdominal segment. }\end{array}$ & $\begin{array}{l}\text { Bright yellow, olive green with a broad black } \\
\text { band above. Underside is black. }\end{array}$ & $\begin{array}{l}\text { Similar to male except for } \\
\text { the olive green thin strip } \\
\text { of olive green along the } \\
\text { lateral margins of the first } \\
\text { four abdominal segment. }\end{array}$ \\
\hline
\end{tabular}

andromorphs are found in 54\% of European genera (Cordero \& Andres 1996) and in most cases there is an autosomal locus with sex-limited expression and two or three alleles, one per phenotype (Cordero \& Egido 1998). One of the hypothesis put forward suggests that andromorphs are male-mimics and for this reason they are not recognized by mate searching males and therefore, after first mating they can avoid additional unnecessary mating (Robertson 1985), dedicating this time to feeding and egg maturation. The other hypothesis suggest that andromorphs would be favoured at high population density, because of its male like appearance would result in reduced male disturbance, but at lower population density, they have the risk of never mating (Hinnekint 1987). Although andromorphic females are quite common in Zygoptera, very few andromorphic females have been reported in the libellulids (Corbet 1999). Till date only four andromorph forms of Neurothemis $t$. tullia have been documented (Lahiri 1979; Asahina 1981; Kumar 1988; Mitra 1991) from the northeastern states of India and one from central India (Prasad et al. 2000). Although this is the second report of an andromorph female of Neurothemis $t$. tullia from peninsular India; it is for the first time that an andromorphic female of Neurothemis t. tullia has been reported in gravid condition with viable eggs. Although andromorphy is extremely uncommon in Neurothemis $t$. tullia, the potential for andromorphy to evolve in this species clearly exists. Further studies are required to estimate the frequency of andromorphy in Neurothemis t. tullia population and to determine whether there is sufficient selective pressure for it to be maintained in this species or whether it is simply an artifact of recurrent mutation.

\section{REFERENCES}

Andrew, R.J., K.A. Subramanian \& A.D. Tiple (2008). A Handbook of Common Odonates of Central India. Pub. South Asian Council of Odonatology, India for $18^{\text {th }}$ International Symposium on Odonatology, Nagpur, India, 54pp.

Asahina, S. (1981). Seasonal variation in Neurothemis tullia (Drury) Tombo 24: 12-16.

Corbet, P.S. (1999). Dragonfly Behaviour and Ecology of Odonata. Harley Books, Colchester, England, 829pp.

Cordero, A.R. \& J.A. Andres (1996). Colour polymorphism in Odonates: Females that mimic males? Journal of the British Dragonfly Society 12: 50-60

Cordero, A.R. \& F.J.P. Egido (1998). Mating frequency, population density and female polychromatism in the damselfly, Ischnura graellsii: an analysis of four natural population. Etologia 6: 61-67.

Fraser, F.C. (1936). The fauna of British India including Ceylon and Burma, Odonata-Vol III. Taylor and Francis Ltd., London, 461pp.

Hinnekint, B.O.N. (1987). Population dynamics of Ischnura e. elegans (Vander Linden) (Insecta: Odonata) with special reference to morphological colour change, female polymorphism, multiannual cycles and their influence on behavior. Hydrobiologia 146: 3-31.

Kotarac, M. (1996). A note on the existence of androchrome females in Crocothemis erythraea (Brulle) (Anisoptera: Libellulidae). Notule Odonatologicae 4: 123-124.

Kumar, A. (1988). On the andromorphic female of Neurothemis t. tullia (Dru.) (Anisoptera: Libellulidae) Notule Odonatologicae 3: 12-16.

Lahiri, A.R. (1979). Odonata (Insecta) from different states of north east India. Oriental Insects 13: 119-132.

Mitra, T.R. (1991). Another record of an andromorphic female of Neurothemis t. tullia (Dru.) (Anisoptera: Libellulidae). Notule Odonatologicae 3: 133-134.

Prasad, M., P.P. Kulkarni \& S.S. Talmale (2000). New record of andromorphic females in two species of Neurothemis dragonflies (Odonata: Libellulidae) from central India. Bionotes 2: 54.

Robertson, H.M. (1985). Female dimorphism and mating behavior in a damselfly, Ischnura ramburi: female mimicking male. Animal Behaviour 33: 805-809.

Subramanian, K.A. (2005). Dragonflies and Damselflies of Peninsular India; A Field Guide. Project Landscape, Indian Academy of Sciences, Bangalore, India, 118pp.

Ugemuge, N.R. (1986). The Flora of Nagpur District. Shree Prakashan, Nagpur, India, 497pp. 